UDC 378:371'134

DOI 10.35433/pedagogy.1(96).2019.66-73

\author{
T. I. Shanskova, \\ Doctor of Pedagogics, Associate Professor, \\ (Zhytomyr Ivan Franko State University) \\ doktorshans@ukr.net \\ ORCID : $0000-00 \odot 2-1204-0275$
}

T. S. Guzhanova,

Candidate of Sciences (Philology), Associate Professor,

(Zhytomyr Ivan Franko State University)

gjxtvexrf23@gmail.com

ORCID : $0000-0003-2666-8554$

\title{
ANALYSIS OF THE RESULTS OF THE EXPERIMENTAL WORK IN THE FORMATION OF PEDAGOGICAL KNOWLEDGE OF THE FUTURE TEACHERS IN THE PROCESS OF OBTAINING A SECOND HIGHER EDUCATION
}

The article is highlighting the peculiarities of forming the pedagogical knowledge of the future teacher who acquires the second higher education. Its urgency is conditioned by the need to improve the system of vocational training for future teachers within the context of obtaining their second higher education, as well as the insufficient grounding of theoretical and methodical principles particularly regarding the formation of pedagogical knowledge. Such training should aim at forming an appropriate readiness for teaching, characterized by an accelerated pace of mastering the profession, the relationship between the fundamental foundations of vocational education and humanistic values, and the purpose, content, forms and methods necessary for the implementation of a new type of professional activity. A significant part of this process is the formation of the pedagogical knowledge of future teachers. In the course of the research, on the basis of scientific literature analysis and theoretical modeling with the application of system analysis, the andragogical model of professional training of future teachers was developed, its components were characterized and the

fundamental pedagogical knowledge a teacher must possess was specified. With the aim of improving the formation of future teachers' professional knowledge, an educational-methodological complex (EMC) for their professional training under the conditions of obtaining a second higher education was created. This EMC considers the social demands of a teacher's professional activity, the specifics of correspondence studying and

of obtaining a second education, as well as the specifics of course unit. It provides the informational, methodological and academic support of educational process.

In the article, by using the methods of mathematical statistics, the results of experimental work are presented, showing the positive dynamics of the formation of pedagogical knowledge of students from the experimental groups.

Key words: pedagogical knowledge, andragogical model of professional training of the future teachers in the system of the second higher education, educational-methodological complex (EMC) of professional training of the future teachers, level of readiness for professional pedagogical activity.

Introduction. One of the priorities of the higher school within a modern context is to provide for the state's needs of highly skilled personnel to actively research and develop ways of improving the training of specialists, as stated in the Laws of Ukraine "On Higher Education", "On Education" and other normative documents [10]. In today's conditions of rapid social change, the educational strategy of Ukraine is education throughout life. Article 18 of the Law of Ukraine "On Education" states that adult education is an integral part of lifelong education, aimed at establishing and ensuring the right of every adult to continuous education, taking into account his / her personal needs, priorities of social development and the needs of the economy [10].

Previously, problems of training adults with higher education, of their obtaining a second specialty, did not attract much attention from researchers. The majority of papers in education addressed didactic issues by adapting the theory of teaching children to teaching adults and their gaining education, but these approaches are not always adequate pertaining to current needs. Currently, the improvement of the professional competence of a person with a higher 
education by acquiring another specialty takes place within life's considerations, professional and social experience, and motivation, as well as such difficulties as lack of time, information about the possibility of training, lack of interest or trust, uncertainty in one's potential, etc.

Analysis of recent research and publications. The end of the 20th century witnessed the intensification of scientific research pertaining to the study of the specific educational problems of adults. These included, namely, the history of formation, integration processes and the continuity of adult vocational education (V. Andrushchenko, S. Vershlovskyi, B. Hershunskyi, I. Ziaziun, L. Lukianova, N. Nychkalo, L. Sihaieva, L. Pukhovska, etc.), motivating adult learning activities (A. Markova, G. V. Noll, A. Orlov, L. Fridman, etc.), peculiarities of teaching adult learners (L. Antsyferova, H. Ball, Yu. Kuliutkin, M. Noulz, etc.), and the peculiarities of teaching in the process of adult education (O. Burenkova, E. Dzhons, V. Diachenko, O. Lieontiev, etc.).

The analysis of the survey results conducted among graduate students of pedagogical specialties, who have received a second higher education, showed that during the process of training, future teachers mastered the knowledge of socio-economic, natural science, professional and practical training cycles. At the same time, it was noted that the least developed was the knowledge of specific areas of a teacher's activity and the knowledge of the ways of independently obtaining the necessary professional knowledge [6:212-214].

Therefore, the purpose of the paper is to highlight the results of experimental work on the formation of future teachers' pedagogical knowledge during the process of obtaining a second higher education.

Results and Discussion. The research focused attention on various aspects of future teachers' training. More specifically, on the study of the problem of preparing a future teacher for pedagogical activity (O. Abdullina, S. Vitvytska, O. Dubaseniuk, Yu. Kuliutkin, A. Markova, V. Slastionin, etc.), the formation of a teacher's personality in the process of general pedagogical preparation (I. Bohdanova, Yu. Vyzhevska, O. Vozniuk, V. Kovalchuk, O. Moroz, O. Oleksiuk, O. Piekhota, S. Sysoieva, etc.), ways of professional competence formation (O. Horbenko, A. Kramarenko, I. Solodii, etc.) [5; 8; 9].

Research conducted by O. Antonova, N. Guzii, I. Zyazyun, L. Kondrashova, O. Moroz, and $\mathrm{O}$. Tsokur is oriented on the structuring of scientific pedagogical knowledge and the use of pedagogical theory as a means of raising the level of professionalism of future teachers $[1 ; 10]$.

According to O. Antonova, basic knowledge of pedagogics is a structured set of basic pedagogical notions, theories, concepts, laws, regularities, principles, methods of pedagogical activity, ethical norms, values and professional directions of a future teacher. These are necessary for the implementation of the educational process and are provided by normative documents as a component of the state's standard of higher education [1]. In order to improve the professional training of future teachers who obtain a second higher education, Antonova's andragogical model was substantiated. It includes target-motivational, content-updating, activity-procedural and reflective-evaluative components.

The target-motivational component involves considering the social demands of society as to pedagogical activity, personal goals of adult students in obtaining a second higher education in the humanities, and vocational-cognitive, social and personal motives of educational activity.

The content-updating component includes the knowledge of various disciplines of the students' curriculum, which is characterized by informative saturation, orientation on the availability and perception of educational material by students with various levels of actual readiness for professional activity, and focus on the direct use of the acquired knowledge, skills and abilities in professional activity. 
The activity-procedural component is determined by the formation of professional skills based on the application of effective forms, methods and means of training.

Reflective and evaluative components are characterized by the choice of an individual style in achieving an adequate professional and personal self-rating. This implies the ability of predicting and analyzing the results of one's own work.

On the basis of the developed model, the basic knowledge of the professional and practical cycle of teacher training was specified, which is necessary for a teacher's successful work. This presupposes the acquisition of knowledge regarding: the legislative framework regarding the teaching, upbringing and development of children of various age groups and their social protection; general foundations of pedagogics and the basics of didactics; the theory of education and upbringing; the basics of school science; the fundamentals of pedagogical excellence, including general and special theoretical disciplines in the amount necessary for the professional activity of a teacher; modern forms, methods and techniques of teaching and upbringing of children, including working with students' families; the means of obtaining innovative knowledge for solving professional tasks of teaching activity, and improving the professional excellence level.

The logic of further research suggests the definition of the essence of the teachingmethodical complex, which is a set of normative, organizational and teaching methodological documentation, united by a unified methodology and teaching organization. The study of the basic scientific positions of philosophy, pedagogics, psychology, and andragogy concerning the problem of the professional training of specialists in the humanities, specifically under conditions of a second higher education, has made it possible to significantly improve the teaching and methodological support of this process and to create an educationalmethodological complex (EMP) for training future teachers while obtaining a second higher education. This complex was developed with consideration to social requests for the professional activity of a teacher, methods of andragogy, remote education, various disciplines, and provides informational, methodological and scientific support of the educational process.

Professional pedagogical preparation in higher education institutions is carried out, first of all, through the process of teaching variety of pedagogical disciplines, in particular the course of pedagogics. From the standpoint of didactic laws, the content of training of specialists in the humanities while obtaining a second higher education will be full-scale, provided it is complete, deep enough, balanced as to special and general notions, accomplished, systemic, flexible, efficient and, dynamic. In this context, the comprehension and deep understanding of various components is of the utmost importance. These compenents include the purpose and objectives of vocational education, the relationship with the environment (which influences the definition of its content, as well as the revealing of laws and regularities), the didactic principles of its selection, and design.

The main pedagogical theory aspects of the content of learning are as follows: dependence on social requirements and orders, worldview function of the content of education; social experience as a source of knowledge; the task of comprehensive development of personality; didactic principles as factors of determining the content of education, optimal educationalthematic planning. Due to the small number of classroom hours, the content of correspondence students' education should be as rich in information as possible and accessible to the audience with various readiness levels, aimed at immediate use of acquired knowledge, skills and abilities in professional activities. The content of education can be characterized by its relevance and specification, more specifically, by the problem coverage and its practical and theoretical aspects, as well as by problematization. Problematization includes discussion of controversial and unresolved issues, as well as consideration of possible solutions of the 
problem and their practical significance by ways of replenishing knowledge in the process of self-education [8].

Content optimization of the training of future teachers in obtaining a second higher education based on the analysis of didactic literature includes the following criteria:

- content integrity - implies a sufficiently complete reflection of the requirements put forward by society in definite historical conditions of its development to a teacher's personality, the coverage of the main directions of conceptual and methodological, psychological and pedagogical sciences, of practice and experience of teaching and upbringing of children and youth and their socialization;

- realization of andragogical principles - determining the volume and structure of the training content, with consideration to the psychological and pedagogical features and patterns of adult education;

- rational structuring - including content, forms and methods, types of training in their sequence, continuity, phased course of coursework and intercourse preparation;

- compliance of the content - to the level of vocational and cognitive skills, needs and requirements of adult students;

- correlation of educational materials, scientific and methodological base characterized by coherence in the study of disciplines in the following positions: the development of a balanced plan for studying disciplines in time and consistency; interpretation unity of the categorical-conceptual apparatus; continuity in the formation of didactic knowledge and skills; structural support of optimal combination of theoretical, empirical and applied application of students' didactic knowledge and skills; content balance of disciplines on the basis of a hierarchical sequence of mastering them; clear structuring of educational disciplines with consideration to the system-forming role of didactics; step-bystep and phased nature of didactic training.

Research suggests that the strategy of studying pedagogical disciplines should be built up as a convergence of the reproduction of the classical heritage of pedagogical theories and systems in traditional textbooks to a construction of students' own understanding of educational processes and a teacher's actions.

One of the main preconditions of the educational process is the structuring of disciplinespecific educational material on the basis of content units' allocation, the mastering of which is favorable when considering the students' individual-typological features. At the present stage of pedagogical science, such a position is determined by the construction of the logical structure of the content of the discipline material. In terms of these considerations, the priority task of successful differentiation of teaching in the students' study of didactics is to build a logical structure of its content.

In this context, the works of Y. Babansky, A. Baymetov, E. Klimov and others [8] should be referred to. They confirm that for the development of a personality, not only the selection of the content of learning appears significant, but also the formation of an optimal system of activity methods, which determine the individual style of studying. It was determined that the student's individual studying style, which is determined by typological peculiarities within the student's cognitive activity, ensured the achievement of optimal results for that students.

In an experimental study, an individual style of studying was considered to ensure that students with various typological peculiarities achieved optimal assimilation performance within relatively similar conditions and objective requirements of the educational process itself, which is manifested as its own trajectory of learning. The activation of student learning is conditioned by their independent search activity at lectures, seminars, laboratory sessions, and practical and testing classes in the form of material problem content comprehension, discussion of disputable problems and tasks, and independent performance of tasks of various complexity levels. 
The course of pedagogics is the basic one in the training of educators of any specialties and profiles, whose task is to equip future teachers with a clear methodology of pedagogics, with deep and thorough knowledge of the main pedagogical categories and concepts (upbringing, education, training, system, process, principles, organizational forms and methods of upbrining, education and training, scientific basis of education management, etc.). On this basis, the conscious mastering of individual methods and other courses in the pedagogical profile is exercised. In the process of studying this discipline, students must understand the high significance of pedagogical work in the production, economic and social development of mankind. Structurally, the course of pedagogics, as it is known, covers four main sections: general fundamentals of pedagogics; theory of teaching, i.e., didactics; theory and methodology of education; school management.

Such a course structure developed as a result of many years of practice in teaching at pedagogical universities and comprehensive consideration of contemporary achievements in pedagogical theory and practice. It maintains the logic of educational process and the regularities of its functioning. These ensures the organic unity of scientific theory and particular practical recommendations, the educational focus of all parts, sections, themes and paragraphs of this course, a high level of generalization and comprehensiveness which is organically combined with systemic and practical orientation.

The instruction on the course "Pedagogics" is exercised with consideration to the specifics of future teachers' training. Thus, the topic "General Fundamentals of Pedagogics" provides for the consideration of the subject, purpose, and tasks of pedagogics as one of science. Much attention is paid to the analysis of its basic concepts. Future specialists should realize that pedagogical categories are steps in learning the world of childhood, adolescence, youth, various pedagogical phenomena and processes. The set of pedagogical categories can be divided into several groups, each of which represents a separate integrity, constructed in a logical combination and connection. The following categories are singled out:

- pedagogical facts, pedagogical phenomena, pedagogical process, reflecting the "matter" of pedagogical science, the forms of its existence and manifestation;

- upbringing, education, training, development, formation as more special phenomena, which are components of an integral pedagogical process;

- essence, laws and related regularities, connections, dependencies, interactions as a category of objective relations of pedagogical process' internal factors;

- goals, tasks, principles, requirements, rules reflecting the unity of the objective essence of science and the purposefulness of an educator's activity;

- content, knowledge, skills and abilities as categories for defining the program material and the results of pedagogical activities;

- methods, techniques, means, organization and forms belong to the categories of activity, implementation and construction of the pedagogical process

Careful comprehension of the essence of each group of pedagogical categories will help future educators to better understand the deep relationships that exist between pedagogical phenomena and processes. Studying the relationships of pedagogics with related disciplines, students have the opportunity of tracing the basic forms of their interaction. This is particularly true regarding the course "Pedagogics" which includes the use of leading ideas, theoretical positions, and the generalizations of other sciences, in particular psychology and social-pedagogics.

Further on, the students learn the peculiarities of the pedagogical profession, the functions of an educator in modern society, and study the leading factors in the formation of a pupil's personality. These factors include, in particular, the influence of heredity, social conditions, activity, communication, as well as tracing the relationship of education, training and development of a personality, and analyzing age peculiarities of the pupils. 
The section "Didactics" deals with the essence of the teaching process, the content of education in modern school, methods and means of teaching, the forms of organization of the teaching process, and content focusing on teaching cooperation between teachers and pupils in the process of teaching and methodological work at school.

The section "Theory and Methodology of Upbringing" includes the following structural elements: the purpose, essence, content, forms and methods of upbringing of a personality and a team. This section also contains updated topics that reveal the organizational and pedagogical principles of the work of a form master, the role of pedagogical diagnostics in it, the main directions of educational activity, the peculiarities of individual work with pupils, cooperation with parents, and pedagogical fundamentals of the educational activity of public organizations for children and teenagers.

Pedagogics is regarded as a science, which is defined as a certain system of knowledge that developed during the historical development of mankind and characterizes the movement logics of scientific pedagogical thought. Given the structural and logical construction of the course of pedagogics, a general-pedagogical block of knowledge containing the following sections (modules) must be stated: the general foundations of pedagogics (subject, main categories, goals, methodology of pedagogical science); theory and methodology of upbringing (essence, principles, main directions, methods, forms of bringing-up process); the basics of didactics (essence, principles, methods, forms of teaching process); scientific principles of internal school control of the educational and bringing-up process. In addition, taking into account globalization trends in a person's education and personal development throughout his/her life, the main structural units of pedagogical disciplines have been supplemented with the block of knowledge "Continuing education of a teacher", "Professional self-improvement", "Personal self-development" and others. Pedagogical regularities, ideas, principles, forms, methods, means, rules of education and training, which contribute to the growth of cognitive, volitional, emotional spheres of a personality, are analyzed as well.

It is proven that, given the small number of classroom hours, the content of correspondence students' training should be as rich in information as possible, with accessibility of an audience with various levels of actual readiness, aimed at direct using of acquired knowledge, skills and abilities in professional activity.

The idea of application expediency in the course of conducting practical and laboratory classes of teaching methods such as discussion, solution of professionally-oriented tasks, solution of pedagogical tasks, exchange of experience, which should be used in the process of training of adult specialists included in the professional environment, is substantiated. All types of students' practice were improved, with their content and methodological interpretation.

The experiment involved 335 future teachers, gaining a second higher education in Ukrainian and foreign languages, literature, history, and elementary school teaching (178 students - EG, 157 - CG).

Research methods included observation, interviews, and questionnaires that revealed the hidden position of the respondents regarding their profession were applied. A comparative analysis was carried out with the application of statistical methods with the help of O. Smirnov's methodology [7].

In order to determine the effectiveness of the tasks and to achieve certain levels of readiness, a statistical processing of the study results was applied. The applied diagnostic methods allowed for the determination of each student's achievements, as well as the ability to trace the dynamics of formation of their readiness for teacher's professional activity.

According to the structure, components, and criteria of readiness for teacher's professional activity, low, medium, sufficient and high levels of readiness were specified. According to the competency of students' knowledge, each level of readiness was characterized in detail. 
A low level was marked by passing, shallow knowledge of professional and practical cycle for professional activities.

An average level was characterized by knowledge at the level of concepts and representations, which are of a limited, fragmentary nature.

A sufficient level of readiness for professional activity was characterized by a conscious knowledge of disciplines, understanding of basic categories in practical professional cycles, and a deep, strong, systemic knowledge of disciplines.

To assess the level of knowledge competency of future teachers, each level had a distribution in points: low - less than 33 points, average -33 to 48 points, sufficient -49 to 57 points, and high level -58 to 65 points.

After conducting the experiment's formative stage, significant changes in the competency levels of professional knowledge of future teachers were observed (see Table 1). Thus, in the EG, compared to the CG, the number of students who had a low level decreased by $23,3 \%$; the number of students with a sufficient level grew by $34,1 \%$; and the number of students with an average level grew by $17,7 \%$. In the EG after the completion of experimental work, sufficient and high levels of knowledge acquisition were noted as $74,7 \%$ of students compared to $33,7 \%$ in $\mathrm{CG}$.

Table 1

Assessment of the level of knowledge competency in future teachers of experimental (EG) and control groups (CG) before and after the formative stage of the experiment

\begin{tabular}{|l|c|c|c|c|c|c|c|c|}
\hline \multirow{2}{*}{$\begin{array}{l}\text { Competenc } \\
\text { y Leves }\end{array}$} & \multicolumn{4}{|c|}{ Experiment Start } & \multicolumn{3}{c|}{ Experiment Completion } \\
\cline { 2 - 9 } & \multicolumn{2}{|c|}{ EG } & \multicolumn{2}{|c|}{ CG } & \multicolumn{2}{|c|}{ EG } & \multicolumn{2}{c|}{ CG } \\
\cline { 2 - 9 } & A3 & \% & A3 & $\%$ & A3 & $\%$ & A3 & $\%$ \\
\hline Low & 67 & 37,6 & 61 & 38,9 & 13 & 7,3 & 48 & 30,6 \\
\hline Average & 54 & 30,3 & 47 & 29,9 & 32 & 18,0 & 56 & 35,7 \\
\hline Sufficient & 43 & 24,2 & 38 & 24,2 & 97 & 54,5 & 32 & 20,4 \\
\hline High & 14 & 7,9 & 11 & 7,0 & 36 & 20,2 & 21 & 13,3 \\
\hline
\end{tabular}

Conclusions and perspectives of further study of the problem. Thus, the results of the experimental study showed a significant increase in the level of knowledge competency of future teachers who are obtaining a second higher education in experimental groups, compared to the control groups. Such results led to an increase in students' readiness level for professional activity in present conditions, which testifies to the effectiveness of the introduced educational and methodological complex of professional training of a future teacher. Prospects for further research include consideration of the issues surrounding the formation of future teachers' professional competences within the conditions of dual education and ways of improving professional training for the work in the new Ukrainian school.

\section{REFERENCES (TRANSLATED \& TRANSLITERATED)}

1. Antonova, O.Ye. (2003). Formuvannia u maibutnikh uchyteliv bazovykh znan z pedahohiky [Formation of future teachers of basic knowledge in pedagogy]. Naukova shkola: tsentr profesiinoi pidhotovky pedahohichnykh kadriv - Scientific School: Center for the Professional Training of Pedagogical Personnel, 41-63. Zhytomyr: Zhytomyr. derzh. ped. un-t [in Ukrainian].

2. Dubaseniuk, O.A. (Eds.). (2014) Profesiina pedahohichna osvita: stanovlennia $i$ rozvytok pedahohichnoho znannia [Professional pedagogical education: formation and development of pedagogical knowledge]. Zhytomyr: Vyd-vo ZHDU im. I. Franka [in Ukrainian].

3. Klimov, Ye.A. (1996). Psikhologiia professionalnogo samoopredeleniia [Psychology of professional self-determination]. Rostov n/D.: Feniks [in Russian].

4. Kondrashova, L.V. (2007). Vysshaia pedagogicheskaia shkola i Bolonskii protsess: realii i perspektivy [Higher Pedagogical School and the Bologna Process: Realities and Perspectives]. Krivoi Rog: KGPU [in Russian]. 
5. Kramarenko, A.M., Horbenko O.B., Solodiy I.M. (2017) Formuvannia profesiinoi kompetentnosti pedahoha [Formation of professional competence of a teacher] Nauka $i$ osvita - Science and Education, (4), 188-197. Retrieved from https://doi.org/10.24195/2414-4665-2017-10-26 [in Ukrainian].

6. Shanskova, T.I. (2015) Profesiina pidhotovka fakhivtsiv humanitarnoho profiliu $v$ umovakh druhoi vyshchoi osvity: teoriia $i$ metodyka [Professional training of specialists in the humanitarian profile under the conditions of the second higher education: theory and methodology]. O.A.Dubaseniuk.(Ed.). Zhytomyr: Vyd-vo ZHDU imeni Ivana Franka [in Ukrainian].

7. Smirnov, V.I. (1999) Obshchaia pedagogika v tezisakh, definitsiiakh, illiustratsiiakh [General pedagogy in theses, definitions, illustrations]. Moscow: Pedagog. obshchestvoRossii [in Russian].

8. Sysoieva, S.O. (2011) Interaktyvni tekhnolohii navchannia doroslykh [Interactive technologies of adult education]. Kyiv: EKMO [in Ukrainian].

9. Voznyuk, O.V. (2013). Rozvytok osobystosti pedahoha v umovakh tsyvilizatsiinykh zmin: teoriia $i$ praktyka [Development of personality of a teacher in the conditions of civilizational changes: theory and practice]. Zhytomyr: Vyd-voZHDU im. I. Franka [in Ukrainian].

10. Zakon Ukrainy "Pro osvitu" - The Law of Ukraine "On Education"] (n.d.). zakon.rada.gov.ua. Retrieved from https://zakon.rada.gov.ua/go/2145-19 [in Ukrainian].

Received: November 30, 2018

Accepted: February 18, 2019

\section{Аналіз результатів експериментальної роботи з формування педагогічних знань майбутніх учителів у процесі здобуття другої вищої освіти.}

Стаття присвячена висвітленню особливостей формування педагогічних знань майбутніх учителів, які здобувають другу вищу освіту. Ї̈ актуальність зумовлена необхідністю вдосконалення системи професійної підготовки майбутніх вчителів в умовах здобуття другої вищої освіти та недостатньою обтрунтованістю ї̈ теоретичних та методичних засад, зокрема з формування педагогічних знань. Така підготовка має спрямовуватися на формування відповідної готовності до педагогічної діяльності, характеризується прискореним темпом оволодіння професією, взаємозв'язком між фундаментальними основами професійної освіти та гуманістичними иінностями, метою, змістом, формами та методами, щзо необхідні для здійснення нового виду професійної діяльності. Вагоме місце в изьому процесі займає формування педагогічних знань майбутніх учителів.

У ході дослідження на основі аналізу наукової літератури, теоретичного моделювання з використанням системного аналізу було розроблено андрагогічну модель професійної підготовки майбутніх учителів, охарактеризовано ї̈ компоненти та виділено основні педагогічні знання, якими має володіти вчитель. 3 метою покращення формування педагогічних знань майбутніх учителів було створено навчальнометодичний комплекс (НМК) їх професійної підготовки в умовах здобуття другої вищої освіти, який враховує сочіальні запити до професійної діяльності вчителя, специфіку заочної форми навчання та здобуття другої вищої освіти, специфіку навчальних дисциплін, забезпечує інформачійний, методичний та науковий супровід навчального процесу.

У статті за допомогою використання методів математичної статистики подано результати експериментальної роботи, які засвідчили позитивну динаміку сформованості педагогічних знань студентів, які входили до експериментальних груп.

Ключові слова: педагогічні знання, андрагогічна модель професійної підготовки майбутніх учителів в системі другої вищої освіти, навчально-методичний комплекс (НМК) професійної підготовки майбутніх учителів, рівні готовності до професійної педагогічної діяльності. 